Prepared in cooperation with the Indiana Department of Environmental Management

\title{
Regression Models for Estimating Sediment, Nutrient Concentrations and Loads at School Branch at Brownsburg, Indiana, June 2015 through February 2019
}

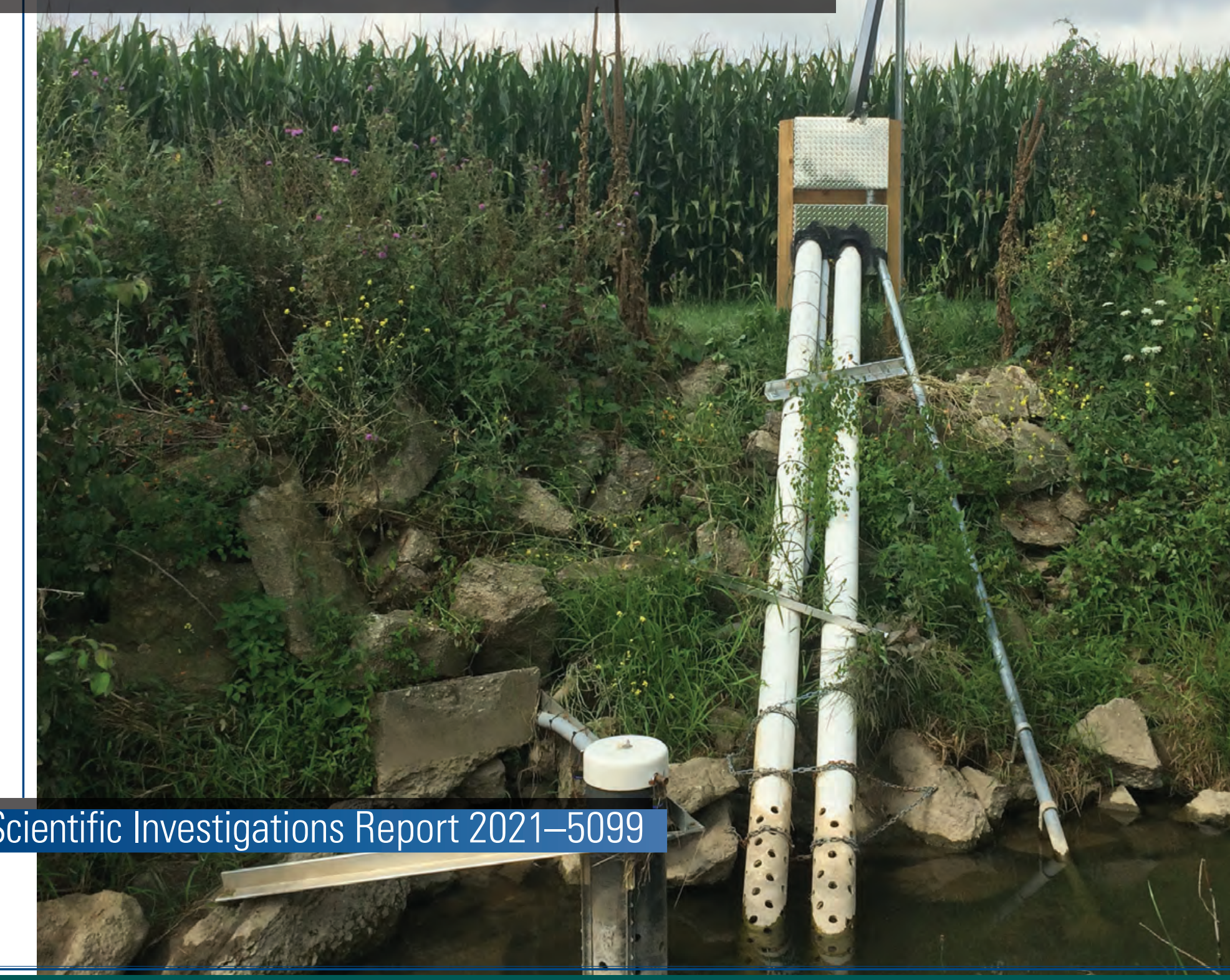

U.S. Department of the Interior

U.S. Geological Survey 
Front-Photograph of the suspergage at School Branch at County Road $750 \mathrm{~N}$ near Brownsburg, Indiana (photograph by Timothy Lathrop, U.S. Geological Survey, 2015).

Back-Photograph looking north at School Branch at County Road $750 \mathrm{~N}$ near Brownsburg, Indiana (photograph by Timothy Lathrop, U.S. Geological Survey, 2015). 


\section{Regression Models for Estimating Sediment, Nutrient Concentrations and Loads at School Branch at Brownsburg, Indiana, June 2015 through February 2019}

By Myles S. Downhour, Aubrey R. Bunch, and Timothy R. Lathrop

Prepared in cooperation with the Indiana Department of Environmental Management

Scientific Investigations Report 2021-5099 


\section{U.S. Geological Survey, Reston, Virginia: 2021}

For more information on the USGS - the Federal source for science about the Earth, its natural and living resources, natural hazards, and the environment—visit https://www.usgs.gov or call 1-888-ASK-USGS.

For an overview of USGS information products, including maps, imagery, and publications, visit https://store.usgs.gov/.

Any use of trade, firm, or product names is for descriptive purposes only and does not imply endorsement by the U.S. Government.

Although this information product, for the most part, is in the public domain, it also may contain copyrighted materials as noted in the text. Permission to reproduce copyrighted items must be secured from the copyright owner.

Suggested citation:

Downhour, M.S., Bunch, A.R., and Lathrop, T.R., 2021, Regression models for estimating sediment, nutrient concentrations and loads at School Branch at Brownsburg, Indiana, June 2015 through February 2019: U.S. Geological Survey Scientific Investigations Report 2021-5099, 15 p., https://doi.org/10.3133/sir20215099.

Associated data for this publication:

Lathrop, T.R., 2021, Data and regression model for suspended sediment for School Branch at CR750N at Brownsburg, Indiana June 23, 2015, to February 6, 2019: U.S. Geological Survey data release, https://doi.org/10.5066/P9YWNBA0.

U.S. Geological Survey, 2020, USGS water data for the Nation: U.S. Geological Survey National Water Information System database, accessed March 25, 2020, at https://doi.org/10.5066/F7P55KJN.

ISSN 2328-0328 (online) 


\section{Contents}

Abstract

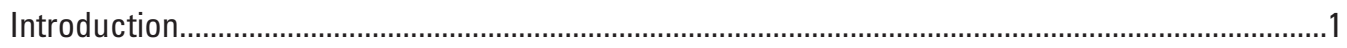

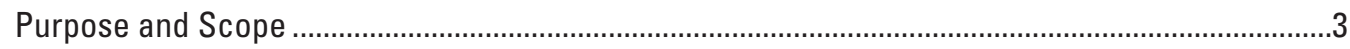

Study Area

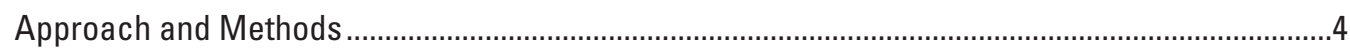

Collection and Analysis of Discrete Water-Quality Samples ...................................................

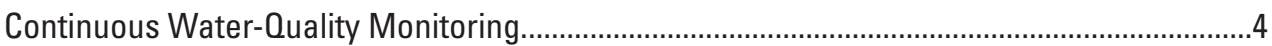

Development and Use of Regression Models......................................................................

Results of Data Collection: Discrete and Continuous Water-Quality Data .........................................

Discrete and Continuous Data............................................................................................

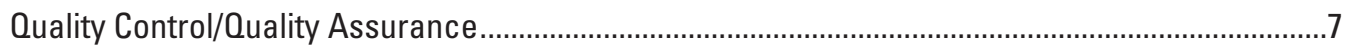

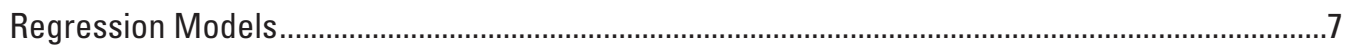

Suspended-Sediment Concentration .......................................................................................

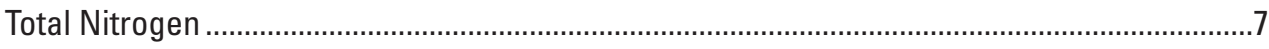

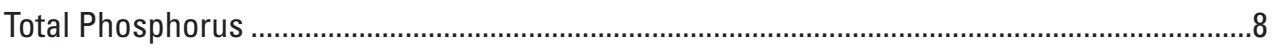

Constituent Load Computation .....................................................................................................

Load Estimation Computations for Suspended Sediment, Total Nitrogen, and Total

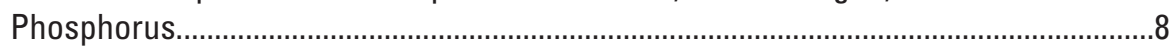

Daily Loads-Suspended Sediment, Total Nitrogen, and Total Phosphorus...............................

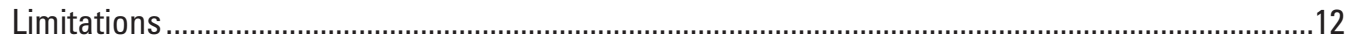

Summary

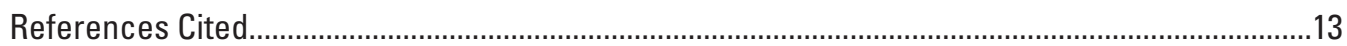

\section{Figures}

1. Map showing the School Branch watershed and the location of the continuous water-quality monitoring station School Branch at CR750N at Brownsburg, Indiana (U.S. Geological Survey station 03353420)...

2. Graphs showing estimated daily suspended-sediment loads with 90-percent prediction intervals for the gaging station School Branch at CR750N at Brownsburg, Indiana (U.S. Geological Survey station 03353420)

3. Graphs showing estimated daily total nitrogen loads with 90-percent prediction intervals for the gaging station School Branch at CR750N at Brownsburg, Indiana (U.S. Geological Survey station 03353420).

4. Graphs showing estimated daily total phosphorus loads with 90-percent prediction intervals for the gaging station School Branch at CR750N at Brownsburg, Indiana (U.S. Geological Survey station 03353420).

\section{Tables}

1. Water-quality constituent data from discrete samples collected by the U.S. Geological Survey at the continuous water-quality monitoring station School Branch at CR750N at Brownsburg, Indiana (U.S. Geological Survey station 03353420 
2. Range of in situ, continuous streamflow, and water-quality values measured at the continuous water-quality monitoring station School Branch at CR750N at Brownsburg, Indiana (U.S. Geological Survey station 03353420).

3. Regression models for selected water-quality constituents at the continuous water-quality monitoring station School Branch at CR750N at Brownsburg, Indiana (U.S. Geological Survey station 03353420).

4. Summary of load statistics for suspended sediment, total nitrogen, and total phosphorus computed from regression and rloadest models for the continuous water-quality monitoring station School Branch at CR750N at Brownsburg, Indiana (U.S. Geological Survey station 03353420).

\section{Conversion Factors}

U.S. customary units to International System of Units

\begin{tabular}{|c|c|c|}
\hline Multiply & By & To obtain \\
\hline \multicolumn{3}{|c|}{ Length } \\
\hline foot $(\mathrm{ft})$ & 0.3048 & meter $(\mathrm{m})$ \\
\hline mile (mi) & 1.609 & kilometer $(\mathrm{km})$ \\
\hline \multicolumn{3}{|c|}{ Area } \\
\hline acre & 0.004047 & square kilometer $\left(\mathrm{km}^{2}\right)$ \\
\hline square mile $\left(\mathrm{mi}^{2}\right)$ & 2.590 & square kilometer $\left(\mathrm{km}^{2}\right)$ \\
\hline \multicolumn{3}{|c|}{ Flow rate } \\
\hline cubic foot per second $(\mathrm{ft} / \mathrm{s})$ & 0.02832 & cubic meter per second $\left(\mathrm{m}^{3} / \mathrm{s}\right)$ \\
\hline \multicolumn{3}{|c|}{ Mass } \\
\hline ton, short $(2,000 \mathrm{lb})$ & 0.9072 & metric ton $(\mathrm{t})$ \\
\hline \multicolumn{3}{|c|}{ Hydraulic gradient } \\
\hline foot per mile ( $\mathrm{ft} / \mathrm{mi})$ & 0.1894 & meter per kilometer $(\mathrm{m} / \mathrm{km})$ \\
\hline
\end{tabular}

Temperature in degrees Celsius $\left({ }^{\circ} \mathrm{C}\right)$ may be converted to degrees Fahrenheit $\left({ }^{\circ} \mathrm{F}\right)$ as ${ }^{\circ} \mathrm{F}=(1.8 \times$ $\left.{ }^{\circ} \mathrm{C}\right)+32$.

Temperature in degrees Fahrenheit $\left({ }^{\circ} \mathrm{F}\right)$ may be converted to degrees Celsius $\left({ }^{\circ} \mathrm{C}\right)$ as ${ }^{\circ} \mathrm{C}=\left({ }^{\circ} \mathrm{F}-\right.$ 32) / 1.8 .

\section{Datum}

Horizontal coordinate information is referenced to the North American Datum of 1983 (NAD 83).

\section{Supplemental Information}

Specific conductance is given in microsiemens per centimeter at 25 degrees Celsius $(\mu \mathrm{S} / \mathrm{cm}$ at $\left.25^{\circ} \mathrm{C}\right)$.

Concentrations of chemical constituents in water are given as milligrams per liter $(\mathrm{mg} / \mathrm{L})$.

Turbidity units are given in formazin nephelometric units (FNU). 


\section{Abbreviations}

PRESS predicted residual error sum of squares

$R^{2} \quad$ coefficient of determination

IDEM Indiana Department of Environmental Management

USGS U.S. Geological Survey 



\title{
Regression Models for Estimating Sediment, Nutrient Concentrations and Loads at School Branch at Brownsburg, Indiana, June 2015 through February 2019
}

\author{
By Myles S. Downhour, Aubrey R. Bunch, and Timothy R. Lathrop
}

\section{Abstract}

Sediment and nutrient transport in the School Branch watershed (in central Indiana west of Indianapolis) is considered to be heavily affected by agricultural land use throughout the watershed. In 2015, the U.S. Geological Survey, in cooperation with the Indiana Department of Environmental Management, deployed continuous water-quality monitors and began collecting discrete water-quality samples at the streamflow-gaging station School Branch at CR750N at Brownsburg, Indiana (U.S. Geological Survey station 03353420). Regression models that estimate concentrations of suspended sediment, total nitrogen, and total phosphorus were developed by relating streamflow and continuously monitored water-quality data to concentrations measured in discrete water-quality samples collected from June 2015 through February 2019. Regression model diagnostics indicated that streamflow and sensor-measured turbidity concentrations explained about 95 percent of the variation in suspended-sediment concentration and 73 percent of the variation in total phosphorus concentration. Similarly, streamflow and sensor-measured nitrate plus nitrite concentrations explained about 97 percent of the variation in total nitrogen concentrations.

Daily loads of suspended sediment, total nitrogen, and total phosphorus were computed from regression model concentrations and instantaneous streamflow. The estimated mean daily suspended-sediment discharge (June 2015 through February 2019) was 1.184 tons per day; the estimated median suspended-sediment discharge was 0.053 tons per day. The estimated mean daily total nitrogen discharge (June 2015 through February 2019) was 127.50 pounds per day; the estimated median total nitrogen discharge was 28.49 pounds per day. The estimated mean daily total phosphorus discharge (June 2015 through February 2019) was 12.08 pounds per day; the estimated median total-phosphorus discharge was 1.208 pounds per day.

\section{Introduction}

The School Branch watershed is in Hendricks County, Indiana, and drains into the southwest side of Eagle Creek Reservoir (fig. 1). Before settlement, the School Branch watershed consisted of dense forests and marshland. Extensive anthropogenic changes to School Branch, including ditching and the addition of tile drainage, began shortly after settlement in the 1830s, making the watershed more suitable for agriculture (Hadley, 1914; Tharpe and Quinn, 1915).

The large percentage of agricultural land use (primarily row crops) in the School Branch watershed can substantially affect water quality by influencing the amount of sediment and nutrients transported to streams, lakes, and reservoirs (Bunch and others, 2021; Tedesco and others, 2005). Sediment transported to waterways through soil erosion and runoff is considered a major criterion for streams being listed on the Clean Water Acts 303(d) list of impaired waterways (U.S. Environmental Protection Agency, 2021). Agricultural chemicals, such as nutrients and pesticides, are often bound to or transported along with eroded sediments (Tedesco and others, 2005). Tile drains, which are used extensively to lower water tables and improve crop yields in the Midwest and in School Branch, act as conduits that transport nutrients and often bypass riparian buffers (Tedesco and others, 2005). Within the upper School Branch watershed, best management activities (such as conservation tillage, cover crops, and nutrient management) have been implemented to reduce high concentrations of nutrients, sediment, and fertilizers transported downstream (Tedesco and others, 2005).

The Indiana Department of Environmental Management (IDEM) is a State agency responsible for protecting public health and the environment by assessing the quality of surface water and groundwater. The IDEM fulfills Indiana's responsibilities mandated by the Clean Water Act (Indiana Department of Environmental Management, 2020). In 2015, the U.S. Geological Survey (USGS), in cooperation with IDEM, and through the Clean Water Act Section 319 program, installed a gaging station on School Branch at CR750N at Brownsburg, Indiana, (USGS station 03353420) as part of a larger study (Bunch and others, 2021) to assess water pollution as it relates 

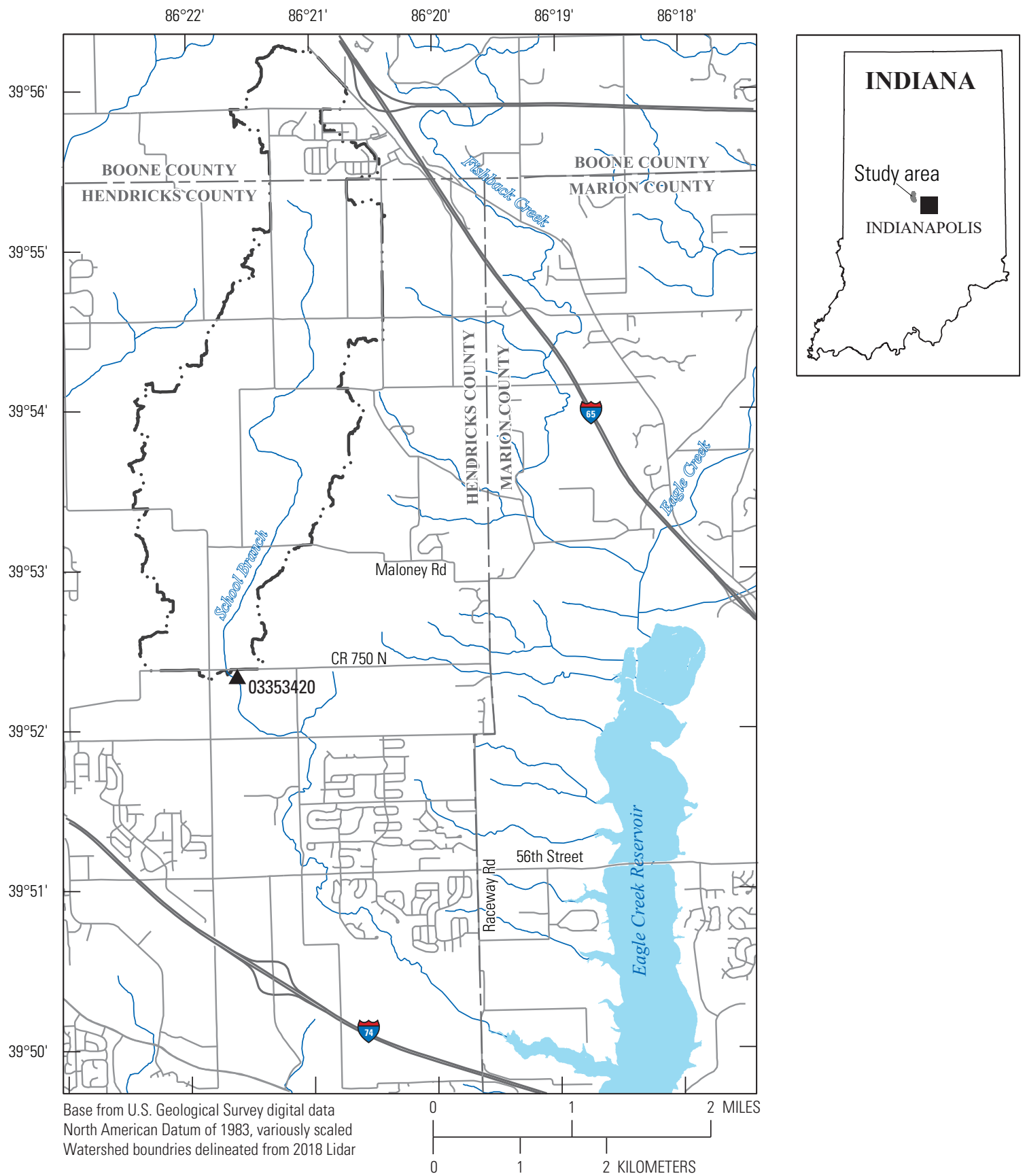

EXPLANATION
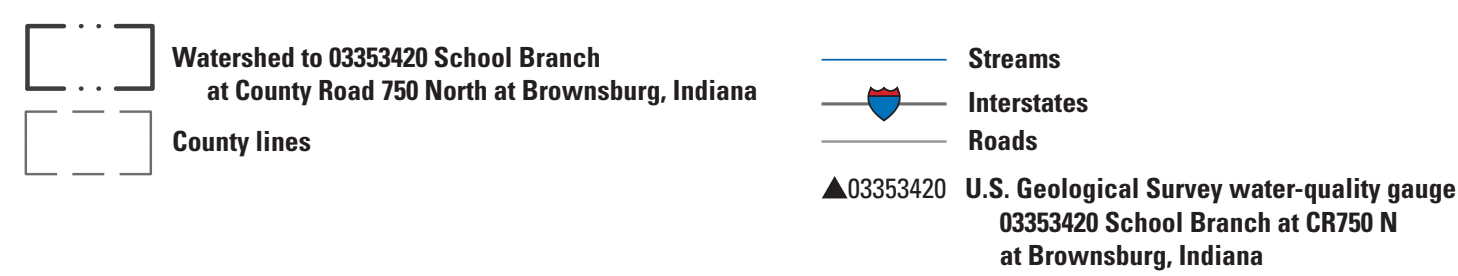

Figure 1. The School Branch watershed and the location of the continuous water-quality monitoring station School Branch at CR750N at Brownsburg, Indiana (U.S. Geological Survey station 03353420). 
to land use and management practices. Instruments were installed to measure streamflow and in situ water-quality properties were installed, and the USGS began collection of discrete water-quality samples at the site. By combining the in situ continuous data with the discrete water-quality samples, concentrations and loads of suspended sediment, total nitrogen, and total phosphorus were estimated using linear regression.

The data discussed in this report were collected as part of a statewide USGS Supergage program. Supergages provide real-time, continuous water-quality at streamflow-gaging stations and groundwater wells and are usually designed to target a specific water resource threat, in this case excess sediment and nutrient loads in the School Branch watershed. A Supergage incorporates real-time and continuous water-quality measurements with field-based measurements and discrete sample collection and laboratory analyses to ensure accuracy of the real-time data (Shoda and others, 2015). Supergages can also be groundwater wells with continuous water levels, in addition to one or more continuous water-quality properties using in situ sensors. Depending on the specific types of water-quality sensors installed at the site, the purpose of a Supergage can include monitoring of sediment, nutrients, or harmful algal blooms. The benefits of a USGS Supergage network include enhancing the ability to model properties important to environmental managers that cannot be measured continuously such as total nitrogen, total phosphorus, and suspended sediment concentrations. The data collected by a USGS Supergage can be used to create models that assess conservation practices, provide early warning for water supply and recreational activities, and aid in evaluation of nutrient reduction strategies (Crain, 2020).

In 2015, the USGS Supergage at School Branch at CR750N at Brownsburg, Indiana (USGS station 03353420, hereafter referred to as School Branch at CR750N), was installed to measure streamflow and continuous water-quality. The gage was installed to facilitate a better understanding of the effects of conservation cropping in the School Branch watershed on water quality and water quantity over 5 to 10 years.

\section{Purpose and Scope}

The purpose of this report is to document the development and application of regression models for estimating suspended sediment, total nitrogen, and total phosphorus concentrations and loads at School Branch at CR750N, using data collected from June 2015 through February 2019. This report follows the template for reporting established in Lathrop and others (2019), where models for estimating sediment and nutrient concentrations and loads were similarly developed for another Indiana site, the Kankakee River at Shelby, Ind. The models summarized in this report can be used to estimate suspended-sediment, total nitrogen, and total phosphorus concentrations and loads at School Branch at CR750N with ongoing model validation. The baseline dataset and developed models will provide IDEM, other agencies, and the public with information and tools to help quantify constituent transport and assess the effects from environmental factors such as changing land use and land-management practices in the School Branch watershed.

\section{Study Area}

In total, School Branch drains an area of 8.31 square miles $\left(\mathrm{mi}^{2}\right.$ ) into Eagle Creek Reservoir (USGS, 2016). School Branch flows in a southeasterly direction from its headwaters in northeast Hendricks County, Ind., to its mouth on the southwest side of the reservoir (fig. 1). Tributaries of School Branch consist of lateral ditches and tiles, draining predominately cropland throughout the watershed. The average slope of the stream is 10.8 feet per mile ( $\mathrm{ft} / \mathrm{mi})$, although most of the drop in elevation occurs within 1 mile of Eagle Creek Reservoir (USGS, 2016; Davis and others, 2019).

School Branch lies within the Tipton Till Plain section of the Central Till Plain physiographic region of Indiana (not shown; Gray and Sowder, 2002). The surficial geology consists primarily of till and is characterized by poorly sorted gravel, sand, silt, and clay. In this region, materials from the Wisconsin glaciation are deposited over most of the materials of previous glaciations (Tedesco and others, 2005). Unconsolidated sediment thickness in the School Branch watershed ranges from $140 \mathrm{ft}$ in the northern portion of the watershed to $260 \mathrm{ft}$ in the southern portion

(Naylor and others, 2015).

Land use in the watershed is primarily agricultural (76 percent) with isolated urban areas (18 percent), forested land (4 percent), and a few small pockets of wetlands $(<1$ percent). Row crop agriculture in the watershed is dominated by corn and soybeans, with a few winter wheat fields and pastures. (USGS, 2016; USDA, 2017). Certain parts of the watershed have used conservation cropping practices since the 1990s in an effort to keep sediment and nutrients on the land, while other areas have been managed under conventional cropping practices. Suburban land use in the watershed has increased steadily since the 1990s. Except for a few hundred acres of Brownsburg, Ind., there are presently no other towns within the School Branch watershed; the residential infrastructure is mainly composed of areas of low- to medium-intensity developed land (USGS, 2015). Homes in the School Branch watershed rely on a combination of septic and sewer systems (Tedesco and others, 2005), although their effect on the water quality of School Branch is not part of this study.

Historically, the School Branch watershed, and most of northeastern Hendricks County, were covered in dense forest and marshland (Hadley, 1914). Beginning in the 1830s, the School Branch area was settled, and shortly thereafter, marshland and waterways began to be converted for agricultural 
use through installation of tiled ditches and artificial mains (Hadley, 1914; Tharpe and Quinn, 1915). As a result, riparian corridors were drained, decreasing localized saturation and improving near-stream areas for agricultural use. From 1780 to 1980,87 percent of presettlement wetlands in Indiana were lost to deliberate drainage (Dahl, 1990).

The drainage area of the Supergage at School Branch at $\mathrm{CR} 750 \mathrm{~N}$ is $4.76 \mathrm{mi}^{2}$ and is about 4-miles upstream from the reservoir (USGS, 2016). This Supergage station is one of three USGS streamflow-gaging stations on School Branch (two of which are Supergages). All data analyzed for this report were collected at the streamflow-gaging station at CR750N at Brownsburg, Indiana.

\section{Approach and Methods}

The development of regression models for suspended sediment, total nitrogen, and total phosphorus relied on the collection of representative discrete water-quality samples and the operation of in situ continuous monitors that span the range of water-quality conditions observed at the site. For this study, representative discrete water-quality samples can be defined as a small subset of sampled water that seeks to proportionally reflect the water-quality characteristics of the entire stream. Additionally, quality-control data were collected throughout the study to assess sampling variability and the potential for bias in the discrete sample results. Field blanks and replicate samples were collected each year and account for 7 percent of all samples collected. Field blanks help to identify potential contamination that may be introduced in the cleaning of equipment or the collection and analytical processing of the samples. Replicate samples were collected to understand the variability associated with collecting environmental data and to ensure sample results were reproducible.

\section{Collection and Analysis of Discrete Water-Quality Samples}

Discrete water-quality samples used in the development of regression models were collected by USGS field crews from October 20, 2015, through February 6, 2019. Initially, water-quality samples were collected on a fixed schedule of every 2 weeks from April through October and monthly during cooler months. Because most of the early sampling was done during lower flows, in late 2016 through the end of the project, the sampling design was altered to target selected high-flow events to better document concentrations throughout the full range of flows in the stream.

Discrete water-quality samples were collected using field protocols as outlined in the USGS National Field Manual for the Collection of Water-Quality Data (USGS, variously dated). During high-flow conditions, the USGS equal-width-increment method was used to collect samples from the downstream side of the bridge near the monitoring site to obtain a flow-weighted-mean concentration for the cross section. During low-flow conditions, equal-width-increment samples were collected by wading near the gage site. During each site visit, the cross section of the stream was sampled twice to provide sufficient sample volume for analysis of (1) nutrients and (2) suspended sediment. Using a churn splitter, the nutrient sample was subset into two containers for evaluation of unfiltered (raw) constituent concentrations and concentrations of filtered constituents smaller than 0.45 micron. Whole-water nutrient samples were preserved with 1 milliliter of sulfuric acid. After preservation, nutrient samples were chilled and shipped for analysis. Each nutrient sample was analyzed by the USGS National Water Quality Laboratory for total and dissolved nitrogen and phosphorus using published methods (Fishman, 1993; O'Dell, 1993; Patton and Kryskalla, 2003, 2011). The entire volume collected for the suspended-sediment sample was analyzed for concentration and sand/fines composition at the USGS Kentucky Sediment Laboratory using analytical methods described by Guy (1969). Results from these two laboratories were reviewed and quality assured by USGS personnel and stored in the USGS National Water Information System (USGS, 2020).

\section{Continuous Water-Quality Monitoring}

On June 23, 2015, the Supergage at School Branch at CR750N was constructed with three water-quality monitors that continuously measure water temperature, specific conductance, $\mathrm{pH}$, dissolved oxygen, turbidity, nitrate plus nitrite concentration, and orthophosphate concentration. The three water-quality monitors were a YSI 6600 5-parameter water-quality sonde (YSI, Yellow Springs, Ohio), a Sea-Bird Submersible Ultraviolet Nitrate Analyzer V2-5 nitrate monitor (SUNA, Bellevue, Washington), and a Wet Labs Cycle P Nutrient Analyzer (Cycle P, Bellevue, Wash.). They were deployed in flow-through polyvinyl chloride (commonly known as PVC) pipes affixed near the right bank of the creek approximately $200 \mathrm{ft}$ downstream from the bridge and situated in well-mixed, flowing water. Beginning on October 4, 2018, the nitrate plus nitrite and orthophosphate monitors were moved to a heated gage house near the right bank of the stream. By continuously pumping water from the creek to a flow-through chamber within the gage house, the instruments continued to measure water-quality of School Branch even during the cold winter months. At the same time, the YSI 6600 was repositioned to the middle of the creek just above the streambed in a steel protective structure. The YSI 6600 and SUNA equipment operate year-round, monitoring water quality every 15 minutes. The Cycle P measures orthophosphate concentration every 2 hours. All continuous measurements are stored at the site on a data-collection platform and are telemetered hourly using the Geostationary Operational 
Environmental Satellite constellation for storage, review, and archival in the publicly available USGS National Water Information System database (USGS, 2020).

Continuous water-quality monitors are operated following documented USGS protocols (Wagner and others, 2006; Pellerin and others, 2013). Each monitor is cleaned and checked for calibration drift, which is an electronic shift in instrument reading of a known standard; this requires roughly biweekly visits from April through October when biofouling from algae and biofilm is greatest and monthly visits from November through March when biofouling is not as prominent. During site visits, the USGS personnel evaluate and record the magnitude of any fouling and calibration drift. The field inspection information is used later to correct for drift and fouling. Data that are rated worse than poor and exceed parameter thresholds cannot be corrected and are removed from the record (Wagner and others, 2006; Pellerin and others, 2013). Infrequently, equipment malfunctions, excessive fouling, and substantial instrument drift resulted in periods of missing continuous data. Minimally twice per year, a second calibrated monitor was used to measure stream water-quality properties (water temperature, specific conductance, $\mathrm{pH}$, dissolved oxygen, and turbidity) across the channel cross section to verify that the in situ monitor provided results representative of average water-quality conditions in the cross section (Wagner and others, 2006).

To assess whether representative concentrations were being obtained, continuous nutrient concentrations measured with in situ sensors were compared to depth- and width-integrated discrete sample concentration data collected during site visits (Lathrop, 2021). Additionally, following USGS protocols, continuous data were checked for bias (consistent overestimate or underestimate of concentration) using methods described by Pellerin and others (2013). Continuous nutrient data collected in this study were determined to be representative of the cross section and were not biased.

\section{Development and Use of Regression Models}

Simple and multiple-linear regression models were developed with concurrent (or nearly concurrent) measurements of discrete and continuous water-quality data collected from October 20, 2015 through February 6, 2019, and archived in a USGS data release (Lathrop, 2021). Regression models were developed following USGS protocols and methods (Helsel and Hirsch, 2002; Rasmussen and others, 2009). Each regression model relates laboratory-analyzed discrete water-quality sample data with in situ, continuous water-quality monitor measurements. Ordinary least-squares regression was used to evaluate and determine the optimal continuous water-quality parameter(s; explanatory variables) to be used as surrogates for each of the discrete constituents (suspended sediment, total nitrogen, and total phosphorus [response variables]). Statistical models for all possible combinations of explanatory and response variables were produced using stepwise regression with smwrStats (Lorenz, 2018) in the R statistical package version 3.5.2 (R Core Team, 2018). A variety of model statistics and diagnostics were used to determine the best predictors of each modeled constituent including tests of significance, standard error, adjusted coefficient of determination $\left(R^{2}\right)$, and the predicted residual error sum of squares (PRESS) statistic. The PRESS statistic is a leave-one-out form of cross-validation that provides a measure of model fit for sample observations not used to develop the regression model. In general, the smaller the PRESS statistic, the better the model's predictive ability (Helsel and Hirsch, 2002).

Explanatory and response variables were evaluated for transformations (logarithm, square root, or square) that linearize the relation or change the distributional characteristics of data, resulting in model residuals that are normally distributed and homoscedastic. To evaluate potential models, diagnostic plots were created to assess how each model's residuals varied as a function of (1) predicted values, (2) normal quantiles, (3) date, and (4) streamflow. Additional plots highlight differences among predicted and observed values, residuals by season, and residuals by year. When comparing models with similar diagnostics, simple linear models, which are those with only one explanatory variable, were given preference to models with two explanatory variables, as is suggested by Rasmussen and others (2009).

The optimal models commonly used a mathematically transformed response variable. In those instances, a smearing estimator was used to correct for bias that occurs when back-transforming model results back into base-10 units (Helsel and Hirsch, 2002). Prediction intervals were computed for each model following methods from Helsel and Hirsch (2002), to define the range of values within which there is 90-percent certainty that the true value occurs.

Potential outliers were identified by inspecting studentized residuals; a studentized residual is the quotient resulting from the division of a residual by an estimate of its standard deviation. Studentized residuals outside of the range of 3 to -3 were considered potential outliers and received further evaluation. Two observations exceeded the outlier threshold. After further examination, both observations were determined to be valid and were retained and used in model development.

Once published, regression models can be used to estimate concentrations and loads of suspended sediment, total nitrogen, and total phosphorus. Daily loads of each constituent are computed from the instantaneous model concentration estimates and instantaneous streamflow using equation 1 (Rasmussen and others, 2009) described in this report.

\section{Results of Data Collection: Discrete and Continuous Water-Quality Data}

During the study period, discrete and continuous water-quality data were collected at School Branch at CR750N. Discrete water-quality samples were manually 
collected at the gaging station and then analyzed at a laboratory.

Discrete water-quality samples reflect the instantaneous concentration of instream constituents at the time of sampling. In situ water-quality monitors were used to record data every 15 minutes and so reflect a wide range of hydrologic conditions including during periods when field personnel are not at the site.

\section{Discrete and Continuous Data}

During the study period, discrete water-quality samples were collected throughout the range of hydrologic and seasonal conditions at School Branch at CR750N. There were 32,44 , and 48 water samples collected, analyzed, and used in the development of the suspended-sediment, total nitrogen, and total phosphorus regression models, respectively (table 1). No censored data (values below detection) were identified in this study. The range of stream conditions measured by the continuous water-quality monitors is summarized in table 2 .

Table 1. Water-quality constituent data from discrete samples collected by the U.S. Geological Survey at the continuous water-quality monitoring station School Branch at CR750N at Brownsburg, Indiana (U.S. Geological Survey station 03353420), June 23, 2015 through February 6, 2019.

[USGS, U.S. Geological Survey; n, sample size]

\begin{tabular}{llllcc}
\hline \multicolumn{1}{c}{ Water-quality constituent } & $\begin{array}{c}\text { USGS parameter } \\
\text { code }\end{array}$ & $\mathbf{n}$ & Range & Median & $\begin{array}{c}\text { Standard devia- } \\
\text { tion }\end{array}$ \\
\hline $\begin{array}{l}\text { Suspended-sediment } \\
\begin{array}{l}\text { Nitrogen, water, unfiltered, total as } \\
\text { nitrogen }\end{array}\end{array}$ & 80154 & 32 & $2-435$ & 38 & 111 \\
$\begin{array}{l}\text { Phosphorus, water, unfiltered, total as } \\
\text { phosphorus }\end{array}$ & 00665 & 44 & $0.55-8.83$ & 3.71 & 1.93 \\
\hline
\end{tabular}

Table 2. Range of in situ, continuous streamflow, and water-quality values measured at the continuous water-quality monitoring station School Branch at CR750N at Brownsburg, Indiana (U.S. Geological Survey station 03353420), June 23, 2015 through February 6, 2019.

[USGS, U.S. Geological Survey]

\begin{tabular}{lccc}
\hline Physical property and units & USGS parameter code & $\begin{array}{c}\text { Range, during discrete sample } \\
\text { collection }\end{array}$ & Range, continuous data \\
\hline $\begin{array}{l}\text { Streamflow, in cubic feet per } \\
\text { second }\end{array}$ & 00060 & $0.02-251$ & $0.01-557$ \\
$\begin{array}{l}\text { Water temperature, in degrees } \\
\quad \text { elsius }\end{array}$ & 00010 & $1.5-24.1$ & $-0.2-28.2$ \\
$\begin{array}{l}\text { Specific conductance, in mi- } \\
\text { crosiemens per centimeter at }\end{array}$ & 00095 & $112-799$ & $65-1,110$ \\
$\quad \begin{array}{l}25 \text { degrees Celsius } \\
\text { pH, in standard units }\end{array}$ & 00400 & & \\
$\begin{array}{l}\text { Dissolved oxygen, in milli- } \\
\text { grams per liter }\end{array}$ & 00300 & $6.9-8.5$ & $6.4-8.0$ \\
$\begin{array}{l}\text { Turbidity, in formazin nephelo- } \\
\text { metric units }\end{array}$ & 63680 & $4.9-17.7$ & $0.1-23.7$ \\
$\begin{array}{l}\text { Nitrate plus nitrite, in milli- } \\
\text { grams per liter }\end{array}$ & 99133 & $0.9-269$ & $0.1-1,570$ \\
\hline
\end{tabular}


These continuous water-quality data were used to provide temporally dense surrogates from which constituent concentrations and loads were estimated by means of regression models.

\section{Quality Control/Quality Assurance}

All field blanks resulted in detections that were at least 80 percent below the median of the environmental sample population (92 percent of blank samples were below minimum laboratory reporting levels). With one exception, all replicate samples analyzed for nutrients and suspended sediment had a relative percent difference that was within 10 percent or had result differences that were less than the minimum reporting limit. One set of total nitrogen replicates collected during storm sampling had a relative percent difference of 15.9 percent. This total nitrogen sample was within laboratory reporting limits and was retained and used in the model.

\section{Regression Models}

Several simple linear and multiple linear regression models were evaluated before selection of the best-fit models to estimate concentrations of suspended sediment, total nitrogen, and total phosphorus. Selected regression models used to compute each constituent are listed in table 3. In-depth model archive summaries are available for each constituent in a companion USGS data release (Lathrop, 2021).

\section{Suspended-Sediment Concentration}

The best-fit suspended-sediment linear regression model is listed in table 3. After evaluating streamflow, specific conductance, and transformed turbidity $\left(\log _{10} T U R B\right.$ or sqrtTURB), the best-fit suspended-sediment linear regression model was created using both streamflow and transformed turbidity as explanatory variables. The explanatory variables used to compute suspended-sediment concentration are logical statistically and physically.

After exploratory statistics indicated that transformed turbidity $\left(\log _{10} T U R B\right.$ or $\left.\operatorname{sqrt} T U R B\right)$ in a simple linear regression model might be used to compute suspended-sediment concentration, diagnostic plots of model residuals as a function of time and streamflow were improved when streamflow was added as an additional explanatory variable (Lathrop, 2021).

\section{Total Nitrogen}

The best-fit total nitrogen linear regression model is listed in table 3. Initially, exploratory statistics indicated that untransformed total nitrogen could be computed directly from continuous nitrate plus nitrite (NOx). Further review of model residuals as a function of time and streamflow indicated that an additional variable(s) or transformation(s) - or both - might help linearize the relation. The addition of streamflow to the model and the transformation of each

Table 3. Regression models for selected water-quality constituents at the continuous water-quality monitoring station School Branch at CR750N at Brownsburg, Indiana (U.S. Geological Survey station 03353420), June 23, 2015 through February 6, 2019.

[n, sample size; RMSE, root mean square error; $R^{2}$, coefficient of determination; PRESS, predicted residual error sum of squares; $\log _{10}$, Logarithm base 10 ; SSC, suspended-sediment concentration; TURB, turbidity in formazin nephelometric units; Q, streamflow in cubic feet per second; TN, total nitrogen; NOx, nitrate plus nitrite in milligrams per liter; sqrt, square root; TP, total phosphorus]

\begin{tabular}{|c|c|c|c|c|c|c|c|}
\hline Constituent & Equation & $\begin{array}{l}\text { Range of vari- } \\
\text { able values used } \\
\text { in model }\end{array}$ & $\mathbf{n}$ & $\begin{array}{c}\text { RMSE } \\
\text { (constitu-ent } \\
\text { units) }\end{array}$ & $\begin{array}{l}\text { Adjusted } \\
\qquad R^{2}\end{array}$ & ESS & $\begin{array}{l}\text { PRESS } \\
\text { statistic }\end{array}$ \\
\hline $\begin{array}{l}\text { Suspended- } \\
\text { sediment } \\
\text { concentration, in } \\
\text { milligrams per } \\
\text { liter }\end{array}$ & $\begin{array}{l}\log _{10} \mathrm{SSC}=0.3681+\left(0.9468^{*}\right. \\
\left.\quad \log _{10} \mathrm{TURB}\right)+\left(-0.0995 * \log _{10} \mathrm{Q}\right)\end{array}$ & $\begin{array}{l}\mathrm{SSC}=2-435 \\
\mathrm{TURB}=0.9-269 \\
\mathrm{Q}=0.05-251\end{array}$ & 32 & 0.144 & 0.95 & 12.4 & 0.796 \\
\hline $\begin{array}{l}\text { Total phosphorus, } \\
\text { water, unfiltered, } \\
\text { total as phospho- } \\
\text { rus, in milligrams } \\
\text { per liter }\end{array}$ & $\mathrm{TP}=\left(0.05138^{*}\right.$ sqrtTURB $)-0.00127$ & $\begin{array}{l}\mathrm{TP}=0.018-0.968 \\
\mathrm{TURB}=0.9-269\end{array}$ & 48 & 0.112 & 0.73 & 1.64 & 0.653 \\
\hline
\end{tabular}


of the variables improved the distributional characteristics of the data and resulted in model residuals that were more normally distributed.

Continuous measurement of nitrate plus nitrite is logical as an explanatory variable because nitrate plus nitrite accounts for most (77 percent) of the total nitrogen concentrations in the discrete samples at School Branch at CR750N. It also is logical for streamflow to be an explanatory variable because rises in streamflow from rainfall and runoff may increase the total nitrogen concentration in the stream because of the entrainment and transport of nitrogen from nonpoint sources. Conversely, rising streamflow may lead to dilution of nitrogen entering the stream from point sources. Streamflow levels also may be indicative of the relative contributions of groundwater, shallow subsurface flow, surface runoff, and subsurface drainage, each of which may contribute higher or lower amounts of nutrients.

\section{Total Phosphorus}

The best-fit total phosphorus model is listed in table 3 . Models which included variables of specific conductance, streamflow, or seasonality variables were tested, but turbidity does the best job of computing total phosphorus over the range of turbidity and streamflow. The use of turbidity as an explanatory variable is logical physically and statistically. In rivers, soluble phosphorus or orthophosphate commonly binds to sediment, whereas particulate phosphorus is commonly transported because of erosion (Mueller and Helsel, 1996). As a result, increased turbidity typically coincides with increased concentrations of total phosphorus within the river (Lathrop, 2021).

\section{Constituent Load Computation}

At School Branch at CR750N, daily loads of suspended sediment, total nitrogen, and total phosphorus were computed for June 23, 2015 through February 6, 2019, from instantaneous regression model concentrations and instantaneous streamflow. "Instantaneous" can be defined as 15-minute unit values. To fill missing periods for load estimation, the resampleUVdata function in the rloadest $\mathrm{R}$ package was used to fill gaps in the explanatory variable time series (Runkel and De Cicco, 2017). The function fills gaps by resampling the original unit-value data to a 15 -minute time interval. The function was set to resample unit values no more than 6 hours away from the nearest data point. For this report, on days when suspended sediment, total nitrogen, and total phosphorus regression model concentrations had gaps greater than the threshold, no daily loads were computed.

\section{Load Estimation Computations for Suspended Sediment, Total Nitrogen, and Total Phosphorus}

Daily loads of suspended sediment, total nitrogen, and total phosphorus were computed for School Branch at CR750N, from June 23, 2015 through February 6, 2019 (figs. 2-4). Loads were calculated at 15-minute intervals for each constituent using equation 1 and then summed to get the total daily load. Regression model loads were not computed when continuous explanatory variables were not available because of (1) exceedance of USGS fouling or drift thresholds that required deletion, (2) in situ instrument failure or removal, or (3) being 10 percent greater than the range of the regression model calibration dataset and exceeding USGS guidelines (Wagner and others, 2006; Rasmussen and others, 2009).

\section{Daily Loads-Suspended Sediment, Total Nitrogen, and Total Phosphorus}

Daily loads of suspended sediment, total nitrogen, and total phosphorus at School Branch at CR750N were computed for each constituent by using the instantaneous regression model concentrations and instantaneous streamflow in the following equation:

$$
C L_{n}=\sum_{i=1}^{n} \frac{\left(C_{i}+C_{i-1}\right) *\left(Q_{i}+Q_{i-1}\right) *\left(t_{i}-t_{i-1}\right)}{4} * c
$$

Where

CLn is the computed load for the desired time period, in tons;

$C_{i} \quad$ is the concentration for the ith time, in milligrams per liter;

$C_{i-} \quad$ is the concentration for the ith minus 1 time, in milligrams per liter;

$Q_{i} \quad$ is the streamflow for the ith value after midnight, in cubic feet per second;

$Q_{i-1}$ is the streamflow for the ith minus 1 value after midnight, in cubic feet per second;

$t_{i} \quad$ is the time for the ith value after midnight;

$t_{i-1} \quad$ is the time for the (ith minus 1) value after midnight;

$c$ is a constant, 0.0027 , for converting the units to tons per day; and

$n \quad$ is the number of instantaneous values within the desired period (day, month, year; Rasmussen and others, 2009).

Instantaneous concentrations and loads could not be calculated when gaps in the explanatory time series exceeded the gap fill threshold.

Estimated daily loads of suspended sediment, total nitrogen, and total phosphorus for this study period are summarized in table 4 . Streamflow throughout the study period ranged from 0.05 to 276 cubic feet per second $\left(\mathrm{ft}^{3} / \mathrm{s}\right)$. The mean instantaneous streamflow during this period was 


\section{A. 2015}

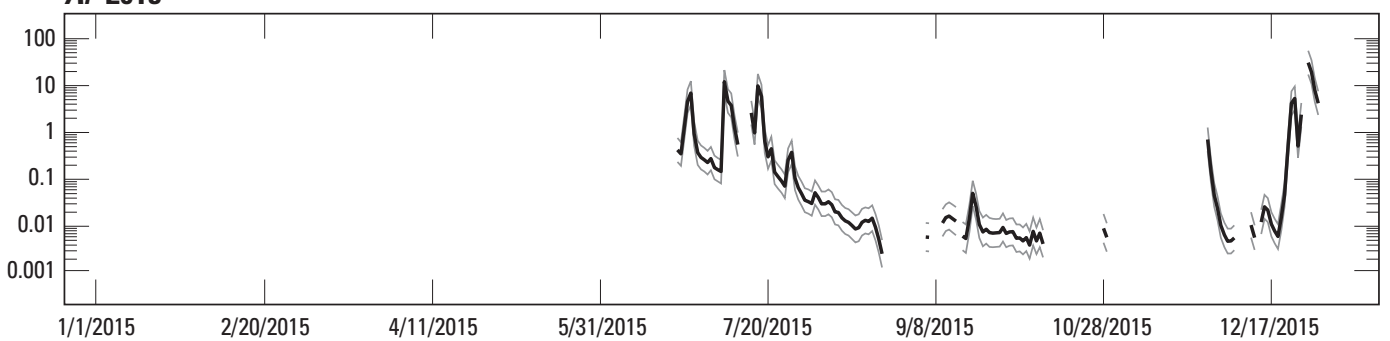

\section{B. 2016}

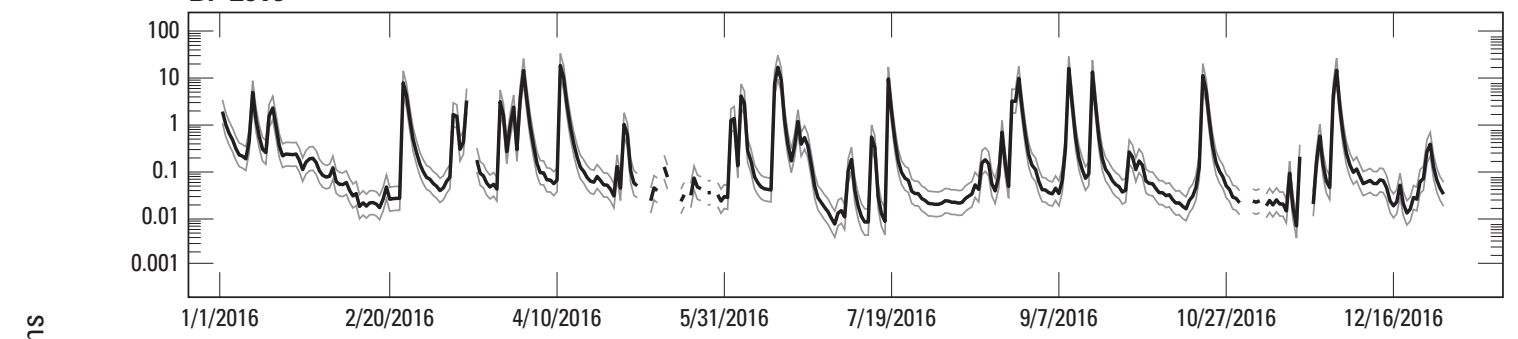

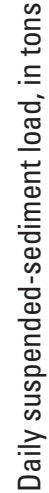

C. 2017

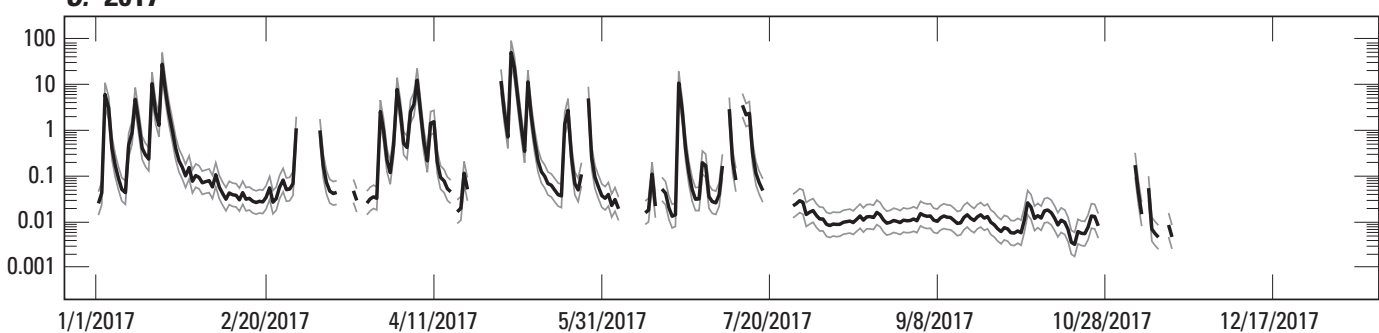

\section{2018}

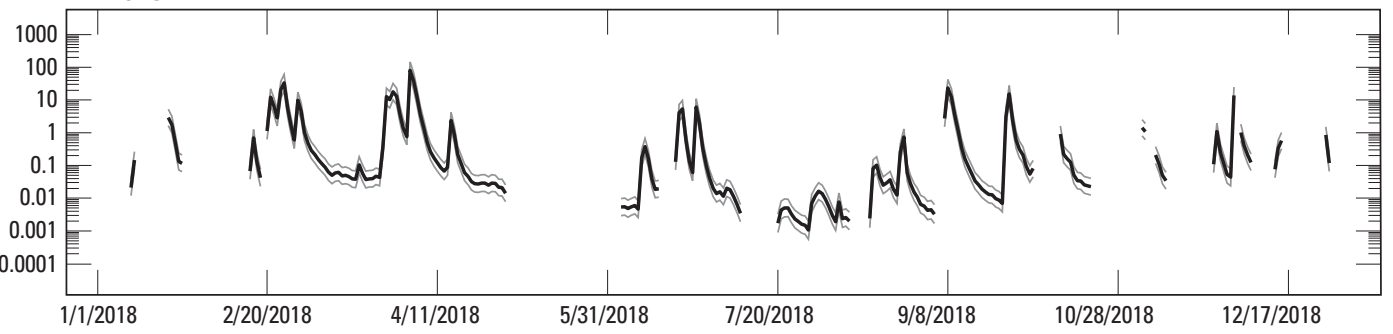

E. 2019

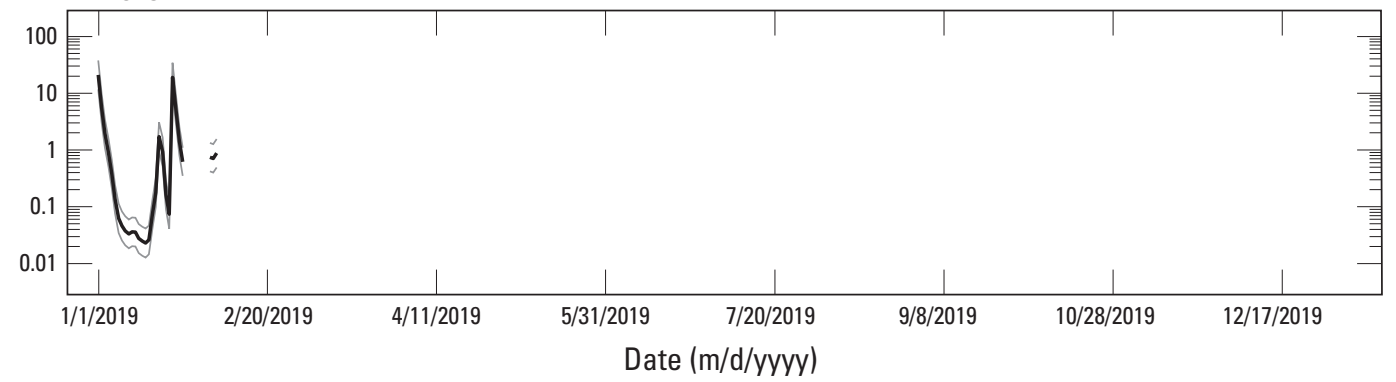

EXPLANATION

Figure 2. Estimated daily suspended-sediment loads with 90-percent prediction intervals for the gaging station School Branch at CR750N at Brownsburg, Indiana (U.S. Geological Survey station 03353420), for June 23, 2015 through February 6, 2019. 


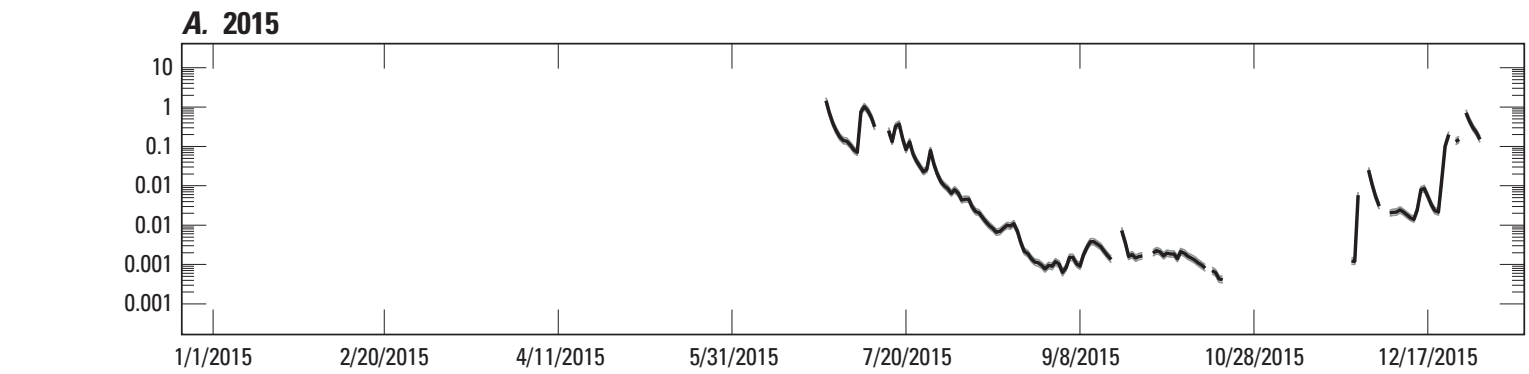

B. 2016

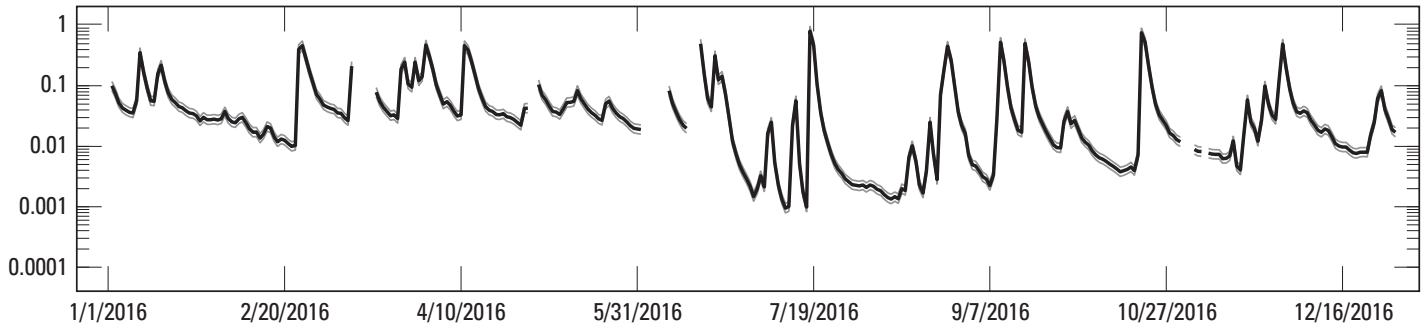

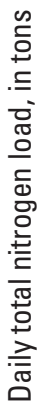

C. 2017

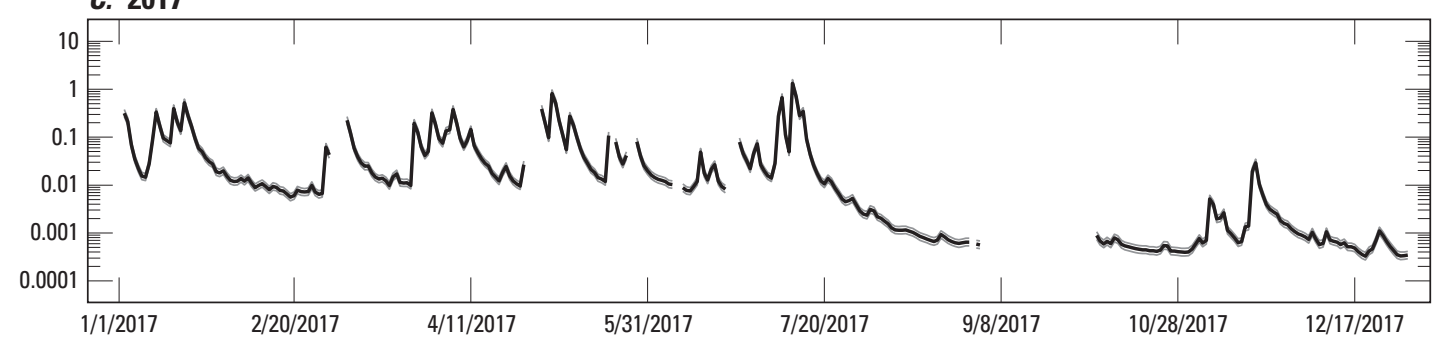

D. 2018

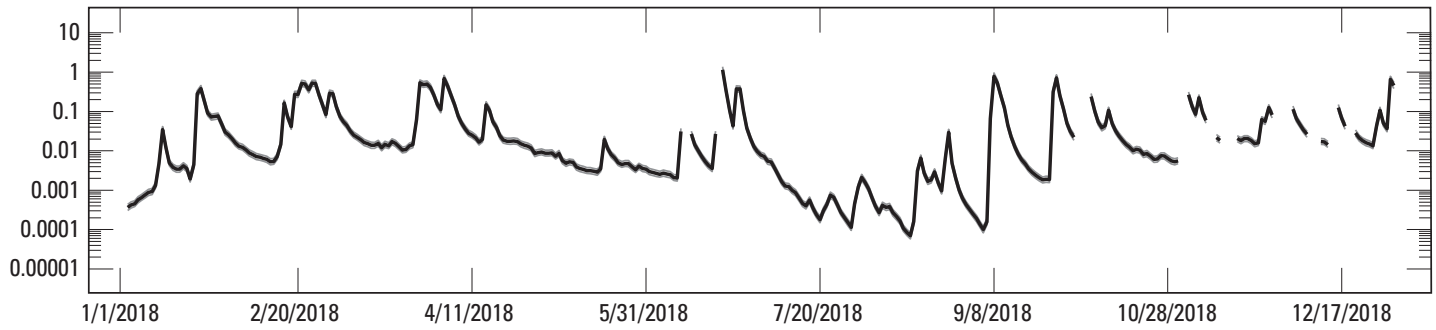

E. 2019

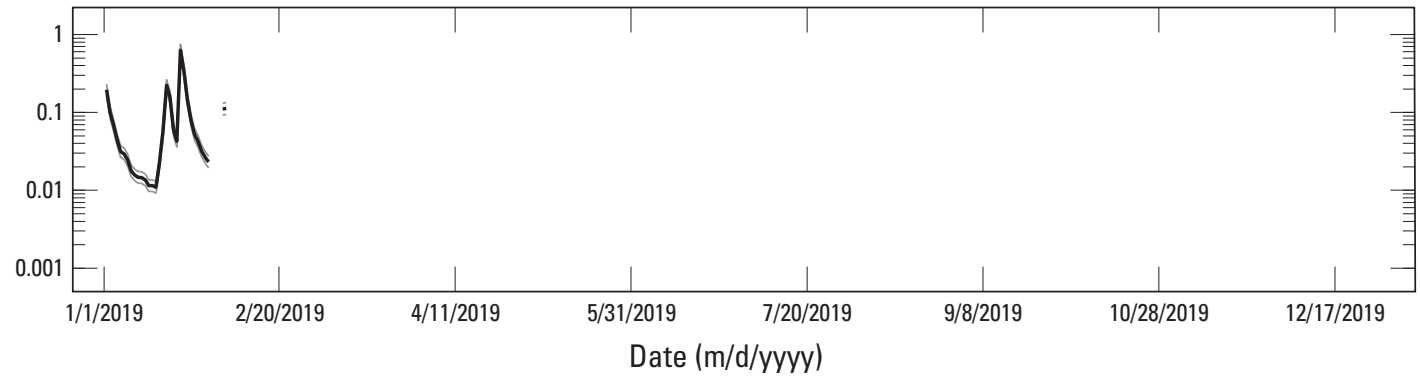

EXPLANATION

Total nitrogen load

Upper and lower 90-percent prediction interval

Figure 3. Estimated daily total nitrogen loads with 90-percent prediction intervals for the gaging station School Branch at CR750N at Brownsburg, Indiana (U.S. Geological Survey station 03353420), for June 23, 2015 through February 6, 2019. 


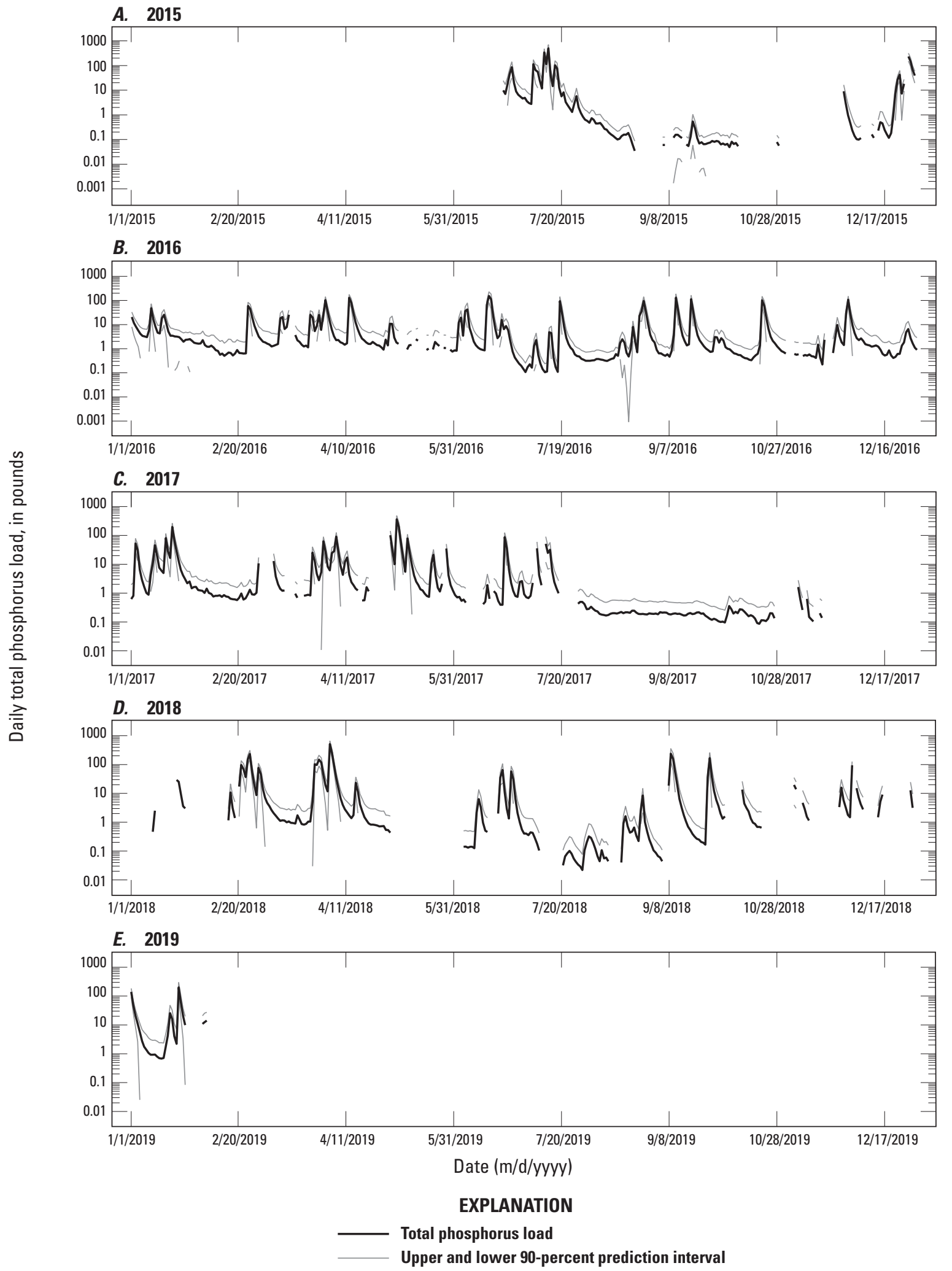

Figure 4. Estimated daily total phosphorus loads with 90-percent prediction intervals for the gaging station School Branch at CR750N at Brownsburg, Indiana (U.S. Geological Survey station 03353420), for June 23, 2015 through February 6, 2019. 
Table 4. Summary of load statistics for suspended sediment, total nitrogen, and total phosphorus computed from regression and rloadest models for the continuous water-quality monitoring station School Branch at CR750N at Brownsburg, Indiana (U.S. Geological Survey station 03353420), from June 23, 2015 through February 6, 2019.

\begin{tabular}{llcc}
\hline \multicolumn{1}{c}{ Constituent } & \multicolumn{1}{c}{ Range in daily loads } & \multicolumn{1}{c}{ Mean daily load } & Median daily load \\
\hline Suspended sediment & & June 23,2015 through February 06,2019 \\
\hline Total nitrogen, as N & $0.001-81.2$ tons & 1.18 tons & 0.053 tons \\
\hline Total phosphorus, as $\mathrm{P}$ & $0.0819-2,908$ pounds & 127.5 pounds & 28.49 pounds \\
\hline
\end{tabular}

$6.29 \mathrm{ft}^{3} / \mathrm{s}$, the median was $1.64 \mathrm{ft}^{3} / \mathrm{s}$, and daily mean streamflow only exceeded $20 \mathrm{ft}^{3} / \mathrm{s}$ approximately 10 percent of the time. Days with daily mean streamflow greater than $20 \mathrm{ft}^{3} / \mathrm{s}$ accounted for 79 percent of the estimated suspended-sediment load (938.9 tons), 53 percent of the estimated total nitrogen load (39.88 tons), and 74 percent of the estimated total phosphorus load (4.49 tons; figs. 2-4). Loads were able to be calculated for 75 percent, 88 percent, and 75 percent of days throughout the study period for suspended sediment, total nitrogen, and total phosphorus, respectively.

\section{Limitations}

Discrete and continuous water-quality data were collected throughout the range of hydrologic and seasonal conditions and are assumed to be independent observations. Samples collected too closely in time may be serially correlated, which is the correlation of a value with one or more values that come after it in sequence (Helsel and Hirsch, 2002). Serial correlation among residuals can bias model statistics that assume independence (for example, PRESS and prediction interval). The sampling frequency at School Branch at CR750N at Brownsburg, Indiana, was every 2 weeks or longer to minimize the potential for serial correlation. Some samples were spaced closer together but were deliberately taken during different runoff events, which makes serial correlation less likely (Helsel and Hirsch, 2002).

The regression models published in this report (table 3) were computed based on concurrent continuous and discrete water-quality measurements at School Branch at CR750N. Although site visits were scheduled to cover the range of seasonal conditions and were later adjusted to capture observed peaks in water-quality properties, discrete samples were not collected during the entire range of in situ continuous measurements. Extrapolation, which is the application of regression models to conditions outside the range of the model calibration data, should be restricted to no more than 10 percent of the maximum or minimum continuous value(s) used in the development of each model (table 2; Rasmussen and others, 2009).

\section{Summary}

The School Branch watershed drains 8.31 square miles of central Indiana. Extensive anthropogenic changes to School Branch began in the mid-19th century, altering the watershed for improved agricultural use, which could have increased the transport potential of sediment and nutrients to downstream waterbodies. The streamflow-gaging station School Branch at CR750N (U.S. Geological Survey station 0353420) was installed in 2015 in cooperation with the Indiana Department of Environmental Management. The gage was installed to provide real-time estimates of concentrations and loads of suspended sediment, total nitrogen, and total phosphorus as part of a larger study to assess the effects of agricultural best practices on water quality.

Continuous and discrete water-quality data, collected from June 2015 through February 2019, were used to develop linear regression models for estimating concentrations of suspended sediment, total nitrogen, and total phosphorus. Regression models indicated strong correlations between turbidity and streamflow with suspended-sediment concentration (adjusted coefficient of determination $\left[R^{2}\right]=0.95$, predicted residual error sum of squares $[\mathrm{PRESS}]=0.796)$, nitrate plus nitrite and streamflow with total nitrogen (adjusted $R^{2}=$ 0.97 , PRESS $=0.0968$ ), and turbidity with total phosphorus (adjusted $R^{2}=0.73$, PRESS $=0.653$ ).

Daily loads of suspended sediment, total nitrogen, and total phosphorus were computed with instantaneous regression model concentration estimates and instantaneous streamflow. The estimated mean daily suspended-sediment discharge (June 2015 through February 2019) was 1.184 tons per day; the median suspended-sediment discharge was 0.053 tons per day. The estimated mean daily total nitrogen discharge (June 2015 through February 2019) was 127.50 pounds per day; the median total nitrogen discharge was 28.49 pounds per day. The estimated mean daily total phosphorus discharge (June 2015 through February 2019) was 12.08 pounds per day; the median total-phosphorus discharge was 1.208 pounds per day. 


\section{References Cited}

Bunch, A.R., McCausland, D.R., and Bayless, E.R., 2021, Hydrologic and ecological investigations in the School Branch watershed, Hendricks County, Indiana - Water years 2016-2018: U.S. Geological Survey Scientific Investigation Report 2021-5061, 74 p., https://doi.org/10.3133/ sir20215061.

Crain, A.S., 2020, The importance of U.S. Geological Survey water-quality super gages: U.S. Geological Survey Fact Sheet 2020-3019, 2 p., https://doi.org/10.3133/fs20203019.

Dahl, T.E., 1990, Wetlands Losses in the United States 1780's to 1980's: Washington, D.C., U.S. Department of the Interior, Fish and Wildlife Service, 13 p. [Also available at https://www.fws.gov/wetlands/documents/Wetlands-Lossesin-the-United-States-1780s-to-1980s.pdf.].

Davis, L.R., Fishburn, K.A., Lestinsky, Helmut, Moore, L.R., and Walter, J.L., 2019, US Topo Product Standard (ver. 2.0, February 2019): U.S. Geological Survey Techniques and Methods book 11, chap. B2, 20 p., 3 plates, scales 1:24,000, 1:25,000, and 1:20,000, https://doi.org/10.3133/tm11b2.

Fishman, M.J., ed., 1993, v. 93-125. Methods of analysis by the U.S. Geological Survey National Water Quality Laboratory-Determination of inorganic and organic constituents in water and fluvial sediments, U.S. Geological Survey Open-File Report, 217 p. [Also available from https://doi.org/10.3133/ofr93125.].

Gray, H.H., and Sowder, K.H., 2002, PHYSIOGRAPHY SR61_IN: Physiographic Regions of Indiana (Indiana Geological Survey, 1:500,000, Polygon Shapefile). Indiana Geological Survey Map. [Also available at https://maps.indiana.edu/].

Guy, H.P., 1969, Laboratory theory and methods for sediment analysis: U.S. Geological Survey, Techniques of WaterResources Investigations, book 5, chap. C1, 58 p. [Also available at https://pubs.usgs.gov/twri/twri5c1/pdf/TWRI_ 5-C1.pdf.].

Hadley, J.V., 1914, History of Hendricks County, Indiana; her people, industries and institutions: Indianapolis, B.F. Bowen \& Co., Inc, 845 p. [Also available at http://purl.dlib.indiana.edu/iudl/inauthors/VAC1000.].

Helsel, D.R., and Hirsch, R.M., 2002, Statistical methods in water resources: U.S. Geological Survey Techniques of Water-Resources Investigations, book 4, chap. A3, 522 p. [Also available at https://doi.org/10.3133/twri04A3.].

Indiana Department of Environmental Management, 2020, Water quality in Indiana: Indiana Department of Environmental Management web page, accessed Mar 18, 2020, at https://www.in.gov/idem/cleanwater/.
Lathrop, T.R., 2021, Data and regression model for suspended sediment for School Branch at CR750N at Brownsburg, Indiana June 23, 2015, to February 6, 2019: U.S. Geological Survey data release, https://doi.org/10.5066/P9YWNBAQ.

Lathrop, T.R., Bunch, A.R., and Downhour, M.S., 2019, Regression models for estimating sediment and nutrient concentrations and loads at the Kankakee River, Shelby, Indiana, December 2015 through May 2018: U.S. Geological Survey Scientific Investigation Report 2019-5005, 13 p., https://doi.org/10.3133/sir20195005.

Lorenz, D., 2018, smwrStats-R functions to support statistical methods in water resources: $R$ package version 0.7.6, accessed December, 2019, at, https://github.com/USGS-R/ smwrStats.

Mueller, D.K., and Helsel, D.R., 1996, Nutrients in the nation's waters - Too much of a good thing?: U.S. Geological Survey Circular 1136, 24 p.

Naylor, S., Sperl, B., and Schumacher, J., 2015, UNCONSOLIDATED_THICKNESS DEM 100M_IGS IN.TIF: Unconsolidated Thickness DEM of Indiana (Indiana Geological Survey, 100-Meter TIFF Image): Indiana Geological Survey. [Also available at https://maps.in diana.edu/].

O’Dell, J.W., ed., 1993, Method 365.1, revision 2.0Determination of phosphorus by semi-automated colorimetry. U.S. Environmental Protection Agency, 18 p. [Also available at https://www.epa.gov/sites/production/files/2015-08/documents/method_365-1_1993.pdf.].

Patton, C.J., and Kryskalla, J.R., 2003, Methods of analysis by the U.S. Geological Survey National Water Quality Laboratory-Evaluation of alkaline persulfate digestion as an alternative to Kjeldahl digestion for determination of total and dissolved nitrogen and phosphorus in water: U.S. Geological Survey Water-Resources Investigations Report 2003-4174, 33 p. [Also available at https://doi.org/10.3133/wri034174.].

Patton, C.J., and Kryskalla, J.R., 2011, Colorimetric determination of nitrate plus nitrite in water by enzymatic reduction, automated discrete analyzer methods: U.S. Geological Survey Techniques and Methods, book 5, chap. B8, 34 p. [Also available at https://pubs.usgs.gov/tm/05b08/.].

Pellerin, B.A., Bergamaschi, B.A., Downing, B.D., Saraceno, J.F., Garrett, J.D., and Olsen, L.D., 2013, Optical techniques for the determination of nitrate in environmental watersGuidelines for instrument selection, operation, deployment, maintenance, quality assurance, and data reporting: U.S. Geological Survey Techniques and Methods, book 1, chap. D5, 37 p. [Also available at https://doi.org/10.3133/tm1D5.] 
R Core Team, 2018, R-A language and environment for statistical computing: Vienna, Austria, R Foundation for Statistical Computing, accessed September 12, 2018, at https://www.R-project.org/.

Rasmussen, P.P., Gray, J.R., Glysson, G.D., and Ziegler, A.C., 2009, Guidelines and procedures for computing time-series suspended-sediment concentrations and loads from in-stream turbidity-sensor and streamflow data: U.S. Geological Survey Techniques and Methods, book 3, chap. $\mathrm{C} 4,53 \mathrm{p}$.

Runkel, R.L., and De Cicco, L.A., 2017, Rloadest-River Load Estimation: R package version 0.4 .5 , accessed November, 2020, at https://github.com/USGS-R/rloadest

Shoda, M.E., Lathrop, T.R., and Risch, M.R., 2015, Realtime, continuous water-quality monitoring in Indiana and Kentucky: U.S. Geological Survey Fact Sheet 2015-3041, 4 p., https://doi.org/10.3133/fs20153041.

Tedesco, L.P., Pascual, D.L., Shrake, L.K., Hall, R.E., Casey, L.R., Vidon, P.G.F., and Hernly, E.S., T F.V., Salazar, K.A., Barr, R.C., 2005. Eagle Creek Drainage basin Management Plan: An integrated approach to improved water quality: Eagle Creek Drainage basin Alliance, CE Publication 2005-07, 182 p.

Tharpe, W.E., and Quinn, E.J., 1915, Soil survey of Hendrick County, Indiana: U.S. Department of Agriculture Bureau of Soils Advanced Sheets-Field Operations of the Bureau of Soils, 40 p.

United States Department of Agriculture (USDA), National Agricultural Statistics Service (NASS), Research and Development Division, Geospatial Information Branch, Spatial Analysis Research Section (SARS), 2017, CROPS_2016_USDA_IN.TIF: Crops in Indiana for 2016, derived from National Agricultural Statistics Service (United States Department of Agriculture, 1:100,000, 30-Meter TIFF Image): USDA-NASS Cropland Data Layer, an annual publication begun in 2000. [Also available at https://maps.indiana.edu/].

U.S. Environmental Protection Agency, 2021, Clean Water Act Section 303(d)-Impaired waters and total maximum daily loads (TMDLs): U.S. Environmental Protection Agency web page, accessed March 30, 2021, at https://www.epa.gov/tmdl.

United States Geological Survey, Indiana Geological and Water Survey, 2015, LAND_COVER_2011_USGS_IN: Land cover in Indiana, derived from the 2011 National Land Cover Database (United States Geological Survey, 30-Meter TIFF Image), raster digital data. [Also available at https ://maps.indiana.edu/].
U.S. Geological Survey, [USGS], variously dated, National field manual for the collection of water-quality data: U.S. Geological Survey Techniques of Water-Resources Investigations, book 9, chaps. A1-A10, accessed January 28, 2020, at https://pubs.water.usgs.gov/twri9A.

U.S. Geological Survey, [USGS], 2016, The StreamStats program for Indiana: U.S. Geological Survey web page, accessed December 4, 2019, at https://streamstats .usgs.gov/ss/.

U.S. Geological Survey [USGS], 2020, USGS water data for the Nation: U.S. Geological Survey National Water Information System database, accessed March 25, 2020 at https://doi.org/10.5066/F7P55KJN.

Wagner, R.J., Boulger, R.W., Jr., Oblinger, C.J., and Smith, B.A., 2006, Guidelines and standard procedures for continuous water-quality monitors - Station operation, record computation, and data reporting, version 1.0: U.S. Geological Survey Techniques and Methods, book 1, chap. D3, 51 p., 8 attachments, accessed January 28, 2020, at https://pubs .usgs.gov/tm/2006/tm1D3/. 
For additional information, contact: Director, Colorado Water Science Center U.S. Geological Survey

Box 25046, MS-415

Denver, CO 80225-0046

https://www.usgs.gov/centers/co-water 

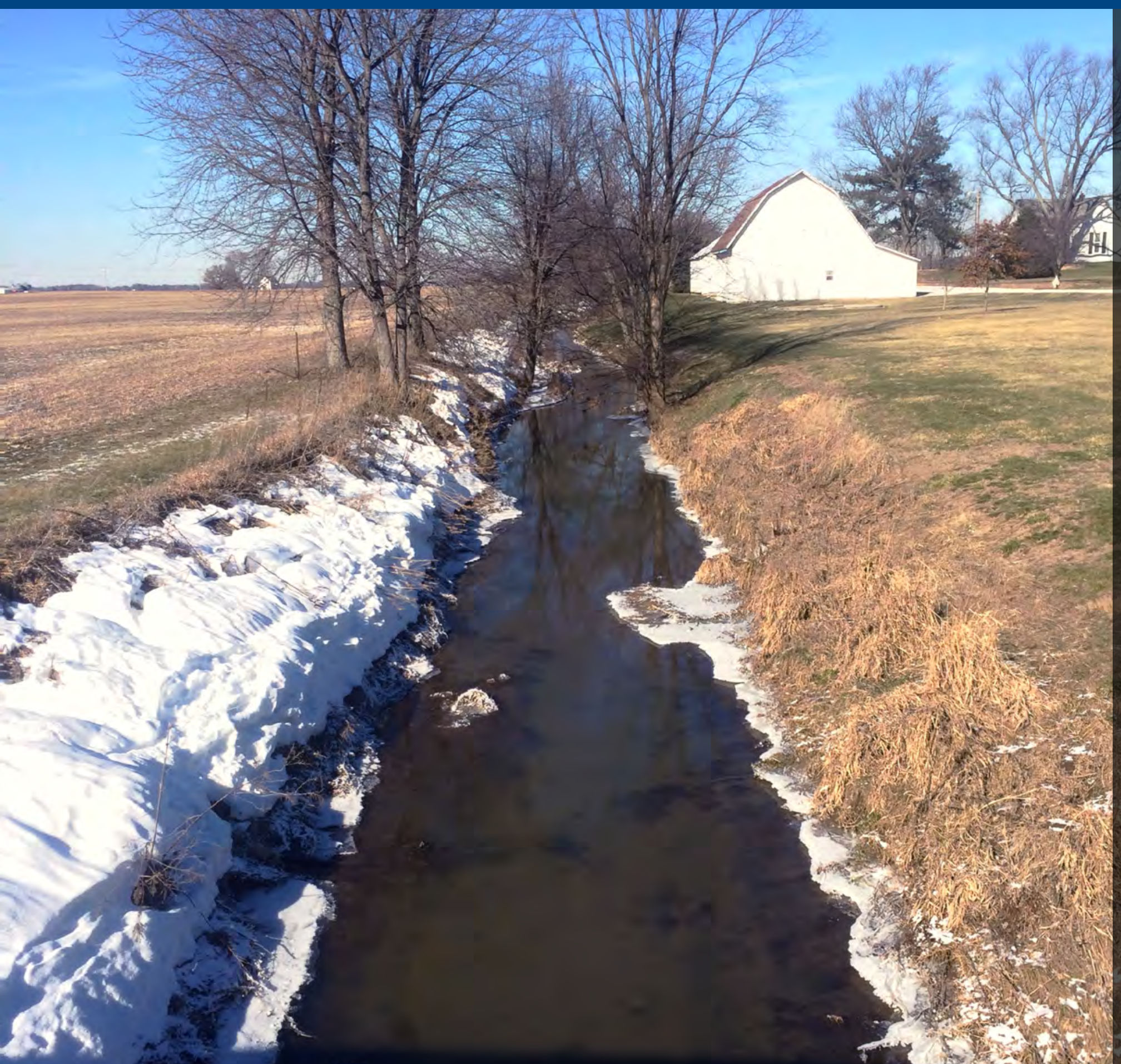

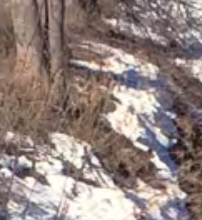
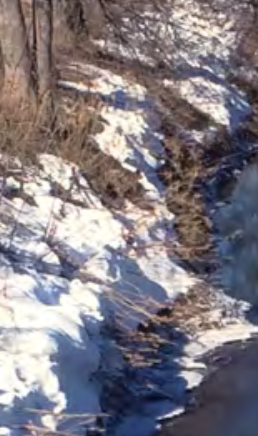
$\frac{3}{3}$
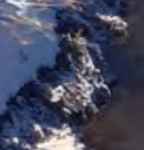

come

$\infty$

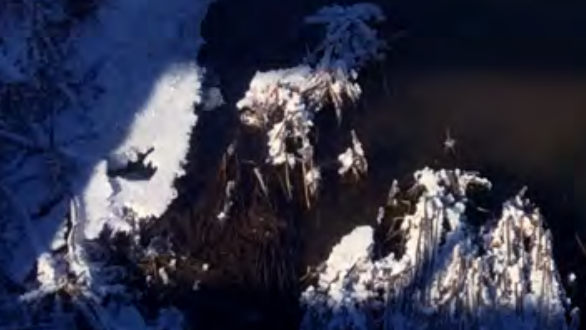

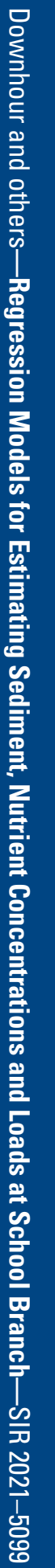

